\title{
Pengaruh asimetri informasi, corporate governance terhadap earnings management pada perusahaan BUMN di Indonesia
}

\author{
Puji Nurhayati ${ }^{1}$, Heidy Paramitha Devi ${ }^{2}$, Amelia Marifatul Azizah ${ }^{3}$ \\ pujinurhayati@unipma.ac.id ${ }^{1}, \underline{\text { heidypd88@ gmail.com }}^{2}$ \\ Universitas PGRI Madiun ${ }^{1,2,3}$
}

$\begin{array}{ll}\text { *Penulis Korespondensi } \\ \text { Diajukan } & : \text { 12 Juni } 2021 \\ \text { Disetujui } & : \text { 8 Januari } 2022 \\ \text { Dipublikasi } & : \text { 15 Januari } 2022\end{array}$

\begin{abstract}
Financial statements are one of the sources of information used to assess the company's financial position and performance. Policies and decisions taken in the process of preparing financial statements will affect the assessment of the company's performance. The choice of accounting policy that management deliberately carried out for profit reporting purposes is called Earnings management. Earnings management is a difficult phenomenon to avoid due to the impact of accruals in the preparation of financial statements. The agency's theory provides the view that earnings management problems can be minimized through corporate governance. The purpose of this research is to provide empirical evidence by analyzing the influence of information asymmetry, the proportion of independent commissioners and the size of the board of commissioners on earnings management of SOEs companies in Indonesia during 2016-2018. Sampling techniques using purposive sampling, obtained 99 sample of STATE-owned enterprises in Indonesia. Data analysis techniques use data regression analysis panel e-views program 9. The data analysis tool uses the Random Effect Model (REM) analysis model. The results showed that the asymmetry of information, the proportion of independent board of commissioners and the size of the board of commissioners did not significantly affect earnings management of STATE-owned enterprises in Indonesia.
\end{abstract}

Keywords: Information Asymmetry, Proportion of Independent Board of Commissioners, Size Of Board of Commissioners, Earnings Management

\section{PENDAHULUAN}

Laporan keuangan merupakan salah satu sumber informasi yang digunakan untuk menilai posisi keuangan dan kinerja perusahaan. Kebijakan dan keputusan yang diambil dalam proses penyusunan laporan keuangan akan mempengaruhi penilaian kinerja perusahaan. pemilihan akuntansi berbasis akrual dalam penyusunan laporan keuangan dilakukan agar dapat mencerminkan kondisi keuangan perusahaan secara riil. Oleh karena itu, manajemen akan memilih kebijakan tertentu dengan tujuan dapat memberikan pelaporan laba yang baik dalam laporan keuangan. Pilihan kebijakan akuntansi yang secara sengaja dilakukan manajemen untuk tujuan pelaporan laba disebut Manajemen laba (earnings management).

Earnings management merupakan fenomena yang sukar untuk dihindari dikarenakan dampak akrual dalam penyusunan laporan keuangan. (Scott, 2003) menyatakan bahwa earnings management merupakan pemilihan kebijakan akuntansi oleh manajer dari standar akuntansi yang ada dan secara alami dapat memaksimumkan utilitas atau nilai pasar perusahaan. Healy dan Wahlen (1998) dalam (Xie, 2001) juga mengungkapkan bahwa earnings management sendiri terjadi ketika manajemen menggunakan keputusan tertentu dalam laporan keuangan dan transaksi untuk mengubah laporan 
keuangan sebagai dasar kinerja perusahaan yang bertujuan untuk menyesatkan pemilik atau pemegang saham atau untuk mempengaruhi hasil kontraktual yang mengandalkan angka-angka akuntansi yang dilaporkan dalam laporan keuangan. (Richardson, 1998) menyatakan hal serupa bahwa terdapat hubungan sistematis antara asimetri informasi dengan tingkat earnings management. Asimetri informasi akan mendorong manajer untuk menyajikan informasi yang tidak sebenarnya terutama jika informasi tersebut berkaitan dengan pengukuran kinerja manajer. Earnings management terjadi dianggap karena adanya asimetri informasi dimana agent memiliki informasi lebih banyak dan akurat dibandingkan dengan principal sehingga agent akan cenderung menyampaikan kondisi perusahaan yang baik walaupun terkadang realitanya kurang mendukung (Rahmawati, 2006) Hal yang senada juga dijelaskan (Scott, 2003) bahwa asimetri informasi merupakan suatu keadaan dimana manajer memiliki akses informasi atas prospek perusahaan yang tidak dimiliki oleh pihak luar perusahaan. Asimetri informasi terdiri dari moral hazard dan advers selection

Fenomena indikasi earnings management telah terjadi diberbagai Negara bealhan dunia termasuk Negara Indonesia. Di Indonesia, perusahaan BUMN yakni PT. Garuda Indonesia yang menyajikan laba bersih di laporan keuangan Tahun 2018 sebesar USD 809.846 atau Rp. 11,49 Milyar (kurs Rp. 14.200/USD). Padahal kuartal III tahun 2018 kerugian perusahaan masih sebesar USD 114,08 juta atau Rp.1,63 triliun. Hal ini berbanding terbalik dg kondisi di tahun 2017 dimana PT. Garuda Indonesia mengalami kerugian sebesar USD 216,58 juta atau setara Rp. 3,09 triliun. Kondisi serupa juga terjadi di PT. PLN Pesero yang menyampaikan laba bersih sebesar Rp 11,56 triliun di tahun 2018. Laba tersebut mengalami kenaikan sebesar Rp.4,42 triliun atau 162,30\% dibandingkan laba tahun 2017. Padahal kuartal III tahun 2018, PLN masih mengalami kerugian sebesar Rp.18,48 triliun akibat kerugian selisih kurs sebesar Rp.17,32 triliun. PT. Pertamina persero juga mengungkapkan hal yang senada terkait dengan laba bersih yang dicapai tahun 2018 yaitu sebesar USD 2,53 Milyar atau Rp. 35,99 triliun padahal kuartal III tahun 2018 laba bersih yang dicapai hanya sebesar Rp.5 triliun. Laba di tahun 2018 tersebut mengalami penurunan dibandingkan tahun 2017 yaitu sebesar USD 2,54 Milyar (cnbcindonesia, 2020).

Adanya fenomena tersebut menjadikan indikasi praktik earnings management di BUMN Indonesia. Teori agensi memberikan pandangan bahwa masalah earnings management dapat diminimalisir melalui corporate governance. Komponen corporate governance dalam meminimalisir praktik earnings management yang dilakukan oleh manajemen dapat melalui mekanisme monitoring untuk menyelaraskan perbedaan kepentingan pemilik dan manajemen antara lain dengan (1) kepemilikan saham oleh institusional karena dianggap sebagai sophicticated investor dengan jumlah kepemilikan yang cukup signifikan dapat memonitor manajemen yang berdampak mengurangi motivasi manajer untuk melakukan earnings management (Midiastuty, 2003); (2) memperbesar kepemilikan saham perusahaan oleh manajemen (manajerial ownership) (Jensen, 1976); (3) proporsi dewan komisaris independen yang membatasi pihak manajemen untuk melakukan earnings management (Peasnell, 2001); (4) ukuran dewan komisaris, dimana jumlah dewan komisaris yang lebih sedikit akan lebih mampu mengurangi indikasi earnings management (Midiastuty, 2003) dan (5) keberadaan komite audit yang dapat mengurangi aktivitas earnings management yang selanjutnya akan mempengaruhi pelaporan keuangan yang salah satunya adalah kualitas laba (Wilopo, 2004). Hal serupa juga disampaikan (Uwuigbe, 2014) bahwa ukuran dewan komisaris dan komisaris independen dapat mengurangi earnings management yang dilakukan oleh manajer dimana dualitas CEO berpengaruh positif dan signifikan terhadap earnings management. (Mashitoh, 2015) juga membuktikan bahwa dewan komisaris dapat meningkatkan kinerja keuangan akan tetapi (Hermiyetti, 2013) mengungkapkan bahwa mekanisme GCG tidak berpengaruh terhadap kinerja keuangan.

Penelitian mengenai asimetri informasi, corporate governance dan earnings management telah banyak dilakukan di Indonesia baik di perusahaan konvensional maupun syariah seperti penelitian (Midiastuty, 2003) ; (Veronica S. d., 2004); (Wedari, 2004); (Boediono, 2005); (Kusumawati, 2005); (Veronica S. d., 2005); (Rahmawati, 2006); (Hanafi, 2006); (Nasution, 2007); (Ujiyantho, 2007); Herawati (2007); (Kusumawati E. P., 2013); (Mashitoh, 2015); (Hermiyetti, 2013) ; (Uwuigbe, 2014); 
dan (Barus, 2015). Namun, penelitian tentang asimetri informasi, corporate governance dan earnings management pada perusahaan BUMN jarang ditemukan.

Tujuan penelitian ini untuk memberikan bukti empiris dengan cara menganalisa pengaruh asimetri informasi, mekanisme corporate governance terhadap earnings management pada perusahaan BUMN di Indonesia selama tahun 2016-2018. Kontribusi penelitian ini adalah 1) bagi investor dapat digunakan sebagai dasar masukan dan pertimbangan dalam pengambilan keputusan investasi saham terutama dalam menilai kualitas laba dalam laporan keuangan; 2) Bagi pengelola pasar modal dapat dijadikan sebagai acuan untuk mendorong perusahaan agar menyajikan informasi yang lebih berkualitas untuk pemangku kepentingan; 3) Bagi pemerintah melalui BAPEPAM dapat mendukung dan mengawasi penyelenggaraan perusahaan; dan 4) Bagi Perusahaan BUMN , hasil penelitian ini dapat memberikan kontribusi pemikiran kepada praktisi penyelenggara perusahaan dalam memahami mekanisme corporate governance serta praktik earnings management.

\section{Teori Agency}

\section{STUDI LITERATUR}

(Jensen, 1976) mengungkapkan bahwa terdapat hubungan antara manajemen dan pemegang saham dimana manajemen sebagai agent dan pemegang saham sebagai principal. Hubungan agency memungkinkan adanya konflik kepentigan antara agent dan principal. Teori agency mengimplikasikan terjadinya asimetri informasi antara agent dan principal dimana agent memiliki informasi lebih banyak dan akurat dibandingkan dengan principal sehingga agent akan cenderung menyampaikan kondisi perusahaan yang baik walaupun terkadang realitanya kurang mendukung. Atas dasar alasan tersebut, agent melakukan earnings management. Oleh karena itu, salah satu cara yang digunakan untuk mengawasi masalah tersebut antara agent dan principal dan untuk membatasi perilaku oportunistik manajemen melalui implementasi Corporate Governance melalui dewan komisaris. Hal ini dikarenakan dewan komisaris memiliki peran yang penting dalam mengendalikan dan mengawasi manajemen, dan perumusan strategi pada perusahaan (Hilman dan Danziel, 2003). Oleh karena itu, dewan komisaris dapat dikatakan sebagai pengambil keputusan untuk mengganti atau meresuffle manajemen puncak (Fama. 1980). Adanya dewan komisaris tersebut manajemen dapat memperoleh informasi sehingga meminimalisir adanya asimetri informasi dan pada akhirnya juga mengurangi earnings management (Rutherford dan Buchholtz, 2007).

Berikut kerangka berpikir dalam penelitian ini:

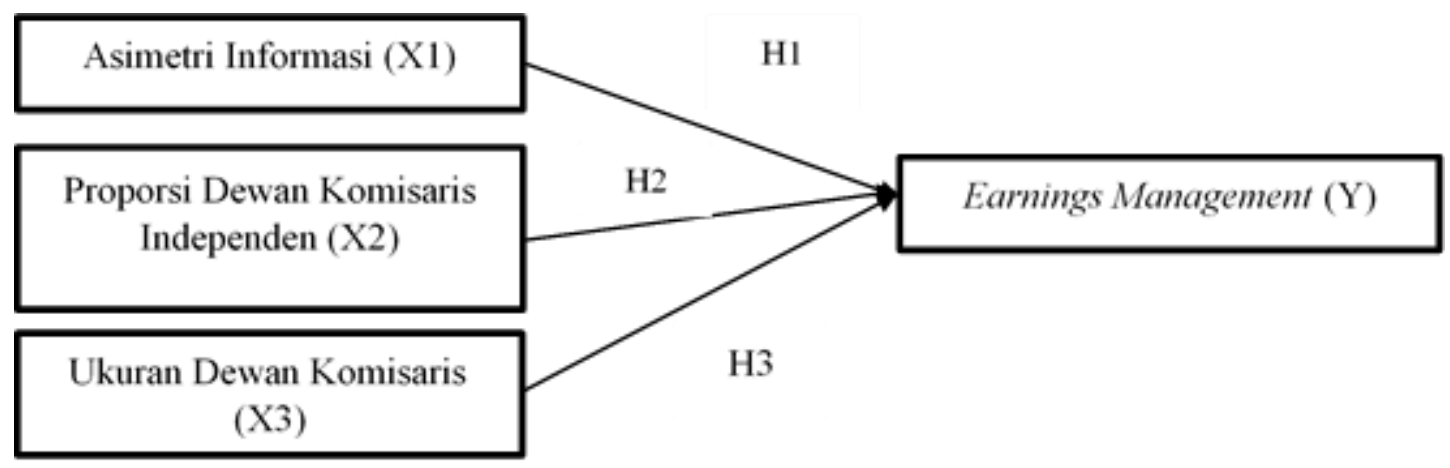

\section{Gambar 1. Kerangka Berpikir}

Berdasarkan kerangka berpikir penelitian di atas maka pengembangan hipotesis dalam penelitian ini adalah sebagai berikut:

\section{Earnings Management}

(Schipper, 1989) menyatakan earnings management sebagai disclousure management dalam pengertian bahwa manajemen melakukan suatu intervensi dengan maksud tertentu terhadap proses 
pelaporan keuangan eksternal secara sengaja untuk memperoleh keuntungan pribadi. Teori akuntansi positif menjelaskan ada tiga hipotesis yang mendorong perusahaan melakukan earnings management yaitu:

1. The bonus plan hypothesis yaitu manajer perusahaan memiliki program bonus yang terkait dengan angka-angka akuntansi cenderung untuk memilik prosedur akuntansi yang menggeser pelaporan laba dari periode mendatang ke periode tahun berjalan (menaikkan laba yang dilaporkan sekarang).

2. The debt convenant hypothesis yaitu kondisi dimana perusahaan yang terancam melanggar konvensi perjanjian hutang cenderung untuk memilik prosedur akuntansi yang menggeser pelaporan laba dari periode mendatang ke periode tahun berjalan.

3. The political cost hypothesis yaitu kondisi dimana semakin besar biaya politis yang dihadapi suatu perusahaan maka manajer cenderung untuk memilih prosedur akuntansi yang menangguhkan pelaporan laba periode mendatang ke periode tahun berjalan (menurunkan laba yang dilaporkan sekarang (Rahmawati dan Qomariyah, 2006).

\section{Pengaruh Asimetri informasi terhadap Earnings Management}

(Rahmawati, 2006) menyatakan bahwa asimetri informasi merupakan suatu keadaan dimana agent memiliki informasi yang lebih banyak tentang perusahaan dan prospek perusahaan dimasa yang akan datang dibandingkan dengan principal. Manajemen yang ingin menunjukkan kinerja yang baik dapat termotivasi untuk memodifikasi laporan keuangan agar menghasilkan laba seperti yang diinginkan oleh pemilik. Asimetri informasi antara agent dan principal dapat memberikan kesempatan kepada manajer untuk melakukan earnings management. (Tarigan, 2011) menyatakan hasil penelitiannya asimetri informasi berpengaruh secara signifikan terhadap earnings management. Hal yang bertolak belakang disampaikan oleh (Firdaus, 2013) bahwa asimetri informasi tidak berpengaruh signifikan terhadap earnings management. (Barus, 2015) juga menyatakan bahwa asimetri informasi tidak berpengaruh signifikan terhadap earnings management. Berdasarkan hasil penelitian di atas maka hipotesis dalam penelitian ini adalah sebagai berikut:

\section{$\mathrm{H}_{1}$ : Asimetri informasi berpengaruh positif dan signifikan terhadap earnings management}

\section{Pengaruh Proporsi Dewan Komisaris Independen terhadap Earnings Management}

Dewan komisaris berfungsi sebagai pengawas kualitas informasi yang terkandung dalam laporan keuangan. (Peasnell, 2001) dan (Midiastuty, 2003) mengungkapkan bahwa keberadaan komisaris independen dapat membatasi pihak agent dalam melakukan earnings management. Berbanding terbalik dengan penelitian (Veronica S. d., 2005) dan (Boediono, 2005) yang menyatakan bahwa proporsi dewan komisaris tidak mempengaruhi praktik earnings management. Hal yang senada juga diungkapkan oleh (Barus, 2015) bahwa proporsi dewan komisaris independen tidak berpengaruh signifikan terhadap earnings management. Berdasarkan hasil penelitian di atas, maka hipotesis dalam penelitian ini adalah:

$\mathrm{H}_{2}$ : Proporsi dewan komisaris independen berpengaruh negative dan signifikan terhadap earnings management

\section{Pengaruh Ukuran Dewan Komisaris terhadap Earnings Management}

(Scott, 2003) menyatakan ukuran dewan komisaris dapat memberi efek yang negative terhadap kinerja. Hal yang berbeda diungkapkan (Midiastuty, 2003) bahwa ukuran dewan komisaris berpengaruh secara signifikan terhadap indikasi earnings management yang dilakukan oleh agent. (Uwuigbe, 2014) mengungkapkan juga jika ukuran dewan komisaris dan komisaris independen dapat mengurangi praktik earnings management yang dilakukan oleh manajemen akan tetapi dualitas CEO berpengaruh positif terhadap earnings management. Hasil yang berbeda pada penelitian (Barus, 2015) bahwa ukuran dewan komisaris tidak berpengaruh signifikan terhadap earnings management

$\mathrm{H}_{3}$ :Ukuran dewan komisaris berpengaruh negative dan signifikan terhadap earnings management 


\section{METODE}

Penelitian ini menggunakan jenis data sekunder dimana data sekunder diperoleh dari annual report perusahaan BUMN di Indonesia selama tahun 2016-2018. Annual report tersebut bersumber pada website masing-masing perusahaan BUMN.

Populasi penelitian ini perusahaan BUMN di Indonesia sejumlah 115 perusahaan selama tahun 2016 sampai tahun 2018. Teknik pengambilan data dengan menggunakan purposive sampling. Kriteria dalam pengambilan sampel tersebut adalah sebagai berikut:

1. Perusahaan BUMN yang telah menerbitkan annual report selama tahun 2016-2018.

2. Tersedianya data terkait dengan lengkap dan sesuai dengan variable yang akan diteliti selama periode tahun 2016-2018.

Variable dependen dalam penelitian ini adalah earnings management sedangkan variable independennya terdiri dari asimetri informasi, proporsi dewan komisaris independen dan ukuran dewan komisaris.

\section{Definisi Operasional dan Pengukuran Variabel Earnings Management}

Earnings management merupakan perilaku yang dilakukan manajer perusahaan untuk meningkatkan atau menurunkan laba dalam proses pelaporan keuangan eksternal dengan tujuan untuk menguntungkan dirinya sendiri. Parameter earnings management adalah sebagai berikut:

$$
E M=\frac{\text { Aktual Modal Kerja }(t)}{\text { Penjualan Periode }(t)}
$$

\section{Asimetri Informasi}

Asimetri informasi adalah suatu keadaan dimana agent mempunyai informasi yang lebih banyak tentang perusahaan dan prospek perusahaan dimasa yang akan datangg dibandingkan principal. Asimetri informasi dirumuskan sebagai berikut:

$$
Q=\frac{M V E+D e b t}{T A}
$$

\section{Proporsi Dewan Komisaris Independen}

Komisaris independen adalah anggota dewan komisaris yang tidak terafiliasi dengan manajemen. Proporsi Dewan Komisaris Independen diukur dengan rumus sebagai berikut:

$$
P D K I=\frac{\text { Jumlah anggota dewan komisaris independen }}{\text { Total dewan komisaris }}
$$

\section{Ukuran Dewan Komisaris}

Ukuran dewan komisaris merupakan jumlah dari anggota dewan komisaris yang terdapat dalam perusahaan. Parameter ukuran dewan komisaris adalah :

$$
U D K=\text { jumlah anggota dewan komisaris di dalam perusahaan }
$$

Sebelum data dianalisis, data terlebih dahulu dilakukan pengujian asumsi klasik. Pengujian asumsi klasik yang dilakukan terdiri dari uji normalitas, uji multikolinieritas, uji heteroskedastisitas dan uji autokorelasi. Sementara uji hipotesis dilakukan dengan menggunakan analisis regresi data panel dengan 3 model panel data yaitu Common Effect Model (CEM), Fixed Effect Model (FEM), dan Random Effect Model (REM). Ketiga model tersebut dibandingkan dan akan diambil model yang terbaik dengan cara uji Chow, Uji Hausman dan Uji Langrange Multiplier. Pengujian ini dilakukan untuk mengetahui pengaruh variable independen berpengaruh baik secara simultan maupun parsial terhadap variable dependen. Program yang digunakan dalam analisis data penelitian ini program eViews 10. Persamaan regresi dalam penelitian ini adalah:

Dimana :

$$
E M=\alpha+\beta 1 . A I+\beta 2 . P D K I+\beta 3 . U D K+e
$$




$\begin{array}{ll}` \alpha & : \text { Konstanta } \\ { }^{'} \beta_{1} & : \text { Koefisien } 1 \\ { }^{\prime} \beta_{2} & : \text { Koefisien } 2 \\ { }^{'} \beta_{3} & : \text { Koefisien } 3 \\ \text { EM } & : \text { Earnings Management } \\ \text { AI } & : \text { Asimetri informasi }\end{array}$

PDKI :Proporsi dewan komisaris independen

UDK : Ukuran dewan komisaris

'e : eror

\section{Analisis Deskriptif}

\section{HASIL}

Analisis deskriptif merupakan tahap awal dalam melakukan analisis data, dimana analisis ini bertujuan untuk mengetahui karakteristik data misalnya mean, median, standar deviasi, nilai maksimal maupun nilai minimal data. Berikut ini table analisis deskriptif dari masing-masing variable.

Table 1

Hasil Statistik Deskriptif

\begin{tabular}{lrrrc}
\hline & EM & AI & PDKI & UDK \\
\hline Mean & $-30422,85$ & 380116,1 & 0,229495 & 4,858586 \\
Median & 0,010000 & $-3125,000$ & 0,200000 & 5,000000 \\
Maximum & 661.4900 & $1.29 \mathrm{E}+08$ & 0,500000 & 9,000000 \\
Minimum & -1928008, & -96194696 & 0,110000 & 2,000000 \\
Std. Deviasi & 221359,7 & 16404269 & 0,088863 & 1,505162 \\
\hline
\end{tabular}

Sumber: Hasil olah data e-views 10.0 (2020)

Pada table 1 menunjukkan bahwa earnings management memiliki nilai rata-rata sebesar 30422,85 , nilai maksimum sebesar 0,010000, nilai minimum sebesar 1928008, dan standar deviasi sebesar 221359,7. Variable asimetri informasi memiliki nilai rata-rata sebesar 380116,1, nilai maksimum sebesar 1.29E+08, nilai minimum sebesar -96194696 dan standar deviasi sebesar 16404269. Variable proporsi dewan komisaris independen memiliki nilai rata-rata sebesar 0,229495, nilai maksimum sebesar 0,500000 , nilai minimum sebesar 0,110000 dan standar deviasi sebesar 0,088863. Variable ukuran dewan komisaris mempunyai nilai rata-rata sebesar 4,858586 , nilai maksimum sebesar 9,000000, nilai minimum sebesar 2,000000 dan standar deviasi sebesar 1,505162 .

\section{Uji Hipotesis}

Penelitian ini dilakukan dengan menggunakan 3 model panel data yaitu Common Effect Model (CEM), Fixed Effect Model (FEM), dan Random Effect Model (REM). Ketiga model tersebut telah dibandingkan dan diambil model yang terbaik dengan cara uji Chow, Uji Hausman dan Uji Langrange Multiplier. Berdasarkan hasil olah data menunjukkan bahwa model terbaik menggunakan Random Effect Model (REM). Hal ini dikarenakan hasil uji chow menunjukkan model FEM yang terbaik (nilai probabilitas < 0,05) dan Uji Hausman menunjukkan model REM yang terbaik (nilai probabilitas FEM $>0,05)$ sehingga dilakukan uji langrange Multiplier untuk memastikan bahwa model REM yang terbaik. Dengan demikian, disimpulkan bahwa model REM yang terbaik dari ketiga model tersebut. Berikut table hasil uji REM yaitu

Table 2.

Hasil Uji Random Effect Model (REM)

\begin{tabular}{lccc}
\hline \multicolumn{1}{c}{ Variable } & coeficient & $t$-statistic & Prob. \\
\hline C & $-133366,0$ & $-0,524555$ & 0,6011 \\
Asimetri informasi & $-2,61 \mathrm{E}-05$ & $-0,024209$ & 0,9807 \\
Proporsi dewan & 142407,7 & 0,261237 & 0,7945 \\
komisaris independen & & &
\end{tabular}


Ukuran dewan

14463,30

0,495968

0,6211

komisaris

Table 3

Hasil Uji Random Effect Model (REM)

\begin{tabular}{lr}
\hline \multicolumn{1}{c}{ Weighted Statistics } & \\
\hline$R$-Squared & 0,03131 \\
Adjusted $R$-Squared & $-0,028349$ \\
F-statistic & 0,099453 \\
Prob.(F-statistic) & 0,960131 \\
Durbin-Watson Stat & 1,377183 \\
\hline
\end{tabular}

Sumber: Hasil olah data e-views 10.0 (2020)

*Tingkat signifikansi 0,05\%

Table 2 menunjukkan bahwa variable asimetir informasi memiliki nilai signifikansi sebesar 0,9807 dimana nilai tersebut di atas $0,05(0,9807>0,05)$. Hal ini dapat diartikan bahwa variable asimetri informasi tidak berpengaruh secara signifikan terhadap earnings management sehingga disimpulkan $\mathrm{H} 1$ ditolak. Variable proporsi dewan komisaris independen memiliki nilai signifikansi sebesar 0,7945 dimana nilai tersebut di atas $0,05(0,7945>0,05)$. Hal tersebut berarti variable proporsi dewan komisaris tidak berpengaruh secara signifikan terhadap earnings management sehingga $\mathrm{H} 2$ ditolak. Variable ukuran dewan komisaris memiliki nilai 0,6211 dimana nilai tersebut di atas 0,05 $(0,6211>0,05)$. Hasil tersebut dapat diartikan bahwa ukuran dewan komisaris tidak berpengaruh secara signifikan terhadap earnings management.

\section{Uji Koefisien Determinasi}

Table 3 menunjukkan Uji statistic yang meliputi determinasi (R2), uji signifikansi bersamasama (uji F) dan uji signifikansi parameter parsial (Uji t). koefisien determinasi (R2) menunjukkan 0,03131 yang artinya bahwa $3 \%$ yang mampu dijelaskan oleh himpunan variasi variable independen, sedangkan 97\% dijelaskan oleh variable-variabel lain di luar model penelitian. Hasil uji $\mathrm{F}$ menunjukkan bahwa nilai $\mathrm{F}$ sebesar 0,099453 dengan nilai probabilitas sebesar 0,960131 sehingga dapat disimpulkan bahwa seluruh variable asimetri informasi, proporsi dewan komisaris independen dan ukuran dewan komisaris secara bersama-sama tidak berpengaruh secara signifikan terhadap earnings management.

\section{PEMBAHASAN}

\section{Pengaruh Asimetri informasi terhadap Earnings Management}

Hasil pengujian hipotesis pertaman menunjukkan asimetri informasi tidak berpengaruh secara signifikan terhadap earnings management. Hal ini kemungkinan disebabkan karena kepemilikan BUMN adalah Negara maka pihak agent dan principal dapat mengaskes informasi dengan kekuatan yang sama besar. Sehingga, principal dapat mengawasi aktivitas agent dalam mengelola manajemen perusahaan BUMN. Hasil yang serupa disampaikan oleh (Schipper, 1989)bahwa asimetri informasi tidak berpengaruh signifikan terhadap earnings management. (Barus, 2015) juga menyatakan bahwa asimetri informasi tidak berpengaruh signifikan terhadap earnings management. Namun, hasil yang berbeda dalam penelitian (Tarigan, 2011) menyatakan hasil penelitiannya asimetri informasi berpengaruh secara signifikan terhadap earnings management.

\section{Pengaruh Proporsi Dewan Komisaris Independen terhadap Earnings Management}

Hasil pengujian hipotesis kedua menunjukkan proporsi dewan komisaris independen tidak berpengaruh secara signifikan terhadap earnings management. Berdasarkan Agency theory yang menjelaskan jika manajemen terdiri dari dewan komisaris yang berperan sebagai pengawas kinerja dan perilaku manajemen serta audit kualitas manajemen. Peran tersebut dilakukan untuk mencegah 
dan mengurangi adanya praktik earnings management. Akan tetapi, kaitannya dengan perusahaan BUMN dimana kepemilikan pemeritah sering kali dibebani misi-misi khusus diluar pencapaian keuntungan maka dalam manajemenpun harus memperhatikan pihak-pihak yang terkait dengan korporasi secara luas sehingga jumlah dewan komisaris dalam pengambilan keputusan juga mempertimbangkan berbagai aspek dalam lingkungan beroperasi. Hasil penelitian ini berbanding lurus dengan (Veronica S. d., 2005) dan (Boediono, 2005) yang menyatakan bahwa proporsi dewan komisaris tidak mempengaruhi praktik earnings management. Hal yang senada juga diungkapkan oleh (Barus, 2015) bahwa proporsi dewan komisaris independen tidak berpengaruh signifikan terhadap earnings management. Namun, (Peasnell, 2001) dan (Midiastuty, 2003) mengungkapkan bahwa keberadaan komisaris independen dapat membatasi pihak agent dalam melakukan earnings management.

\section{Pengaruh Ukuran Dewan Komisaris terhadap Earnings Management}

Hasil pengujian hipotesis ketiga menunjukkan ukuran dewan komisaris tidak berpengaruh secara signifikan terhadap earnings management. Hal ini kemungkinan dikarenakan kepemilikan BUMN berkaitan dengan dana public sehingga agent harus mengetahui batasan-batasan masalah etika dan moral, hokum, kebijakan pemerintah, lingkungan hidup, social, budaya, politik dan ekonomi dalam mengambil keputusan. Hasil yang sama dalam penelitian (Barus, 2015) bahwa ukuran dewan komisaris tidak berpengaruh signifikan terhadap earnings management. (Scott, 2003) menyatakan ukuran dewan komisaris dapat memberi efek yang negative terhadap kinerja. Hal yang berbeda diungkapkan (Midiastuty, 2003) bahwa ukuran dewan komisaris berpengaruh secara signifikan terhadap indikasi earnings management yang dilakukan oleh agent. (Uwuigbe, 2014) pun juga mengungkapkan juga jika ukuran dewan komisaris dan komisaris independen dapat mengurangi praktik earnings management yang dilakukan oleh manajemen akan tetapi dualitas CEO berpengaruh positif terhadap earnings management.

\section{KESIMPULAN DAN SARAN}

Berdasarkan pemaparan diatas dapat disimpulkan bahwa asimetri informasi, proporsi dewan komisaris independen dan ukuran dewan komisaris tidak berpengaruh secara signifikan terhadap earnings management. Hal ini kemungkinan disebabkan karena kepemilikan BUMN adalah Negara maka pihak agent dan principal dapat mengaskes informasi dengan kekuatan yang sama besar. Sehingga, principal dapat mengawasi aktivitas agent dalam mengelola manajemen perusahaan BUMN.

Penelitian ini memiliki kontribusi teoritis sebagai bukti empiris dan tambahan pengetahuan mengenai earnings management pada sector perusahaan BUMN yang nantinya dapat dikembangkan lebih luas pada penelitian berikutnya. Secara praktis, penelitian ini dapat bermanfaat bagi perusahaan BUMN dalam mengambil kebijakan terkait tata kelola perusahaan dengan mempertimbangkan factor-faktor yang menyebabkan earnings management.

\section{KETERBATASAN PENELITIAN}

Keterbatasan penelitian ini adalah rentang waktu pengamatan terbatas hanya tahun 2016-2018. Selain itu, nilai adjusted R-squared masih tergolong sangat kecil sehingga masih banyak kemungkinan model penelitian lain yang dapat mempengaruhi earnings management pada sector perusahaan BUMN. Bagi penelitian selanjutnya diharapkan dapat menambahkan variable lain terutama variable yang berkaitan dengan earnings management pada sector perusahaan BUMN. 


\section{REFERENSI}

Barus, A. C. (2015). “ Pengaruh Asimetri Informasi, Mekanisme Corporate Governance dan Beban Pajak Tangguhan terhadap Manajemen Laba.”. Jurnal Wira Ekonomi Mikrosil Vol. 5., No. 1. Oktober 2015 .

Boediono, G. S. ( 2005). Kualitas Laba: Studi Pengaruh Mekanisme Corporate Governance dan Dampak Manajemen Laba dengan Menggunakan Analisis Jalur. Simposium Nasional Akuntansi 8 Solo Tanggal 15-16 September 2005. Solo.

cnbcindonesia. ( 2020). laporan-laba-janggal-ojk-minta-bei-periksa-manajemen-garuda. . Jakarta : https://www.cnbcindonesia.com/market/20190502201304-17-70218/.

Firdaus, I. (2013). Pengaruh Asimetri Informasi dan Capital Adique Ratio Terhadap Manajemen Laba. Padang: Fakultas Ekonomi, Universitas Negeri Padang.

Hanafi, S. M. (2006). Corporate Governance: Kajian Empiris Cost of Capital Jakarta Islamic Index (JII) sebagai Ethical Investment. As-Syir'ah, Vol. 40 No. 1.

Hermiyetti, H. a. (2013). The influence of good corporate governance mechanism on earnings management: empirical study in Indonesian Stock Exchange listed company for periods of 2006-2010", . Indonesian Capital Market Review.

Jensen, M. C. (1976). Theory of The Firm: managerial behavior, Agency Cost and Ownership Structure. Journal of Financial Economic 3, Hal 305-360.

Kusumawati, A. A. (2005). Analisis Perbedaan Pengaturan Laba (Earnings Management) pada Kondisi Laba dan Rugi pada Perusahaan Manufaktur di Indonesia. Jurnal Akuntansi dan Keuangan, Vol. 4, No. 1, Hal. 1-20.

Kusumawati, E. P. (2013). Pengaruh Asimetri Informasi dan Mekanisme corporate Governance Terhadap Praktik Earnings management (Kajian Perbandingan Perusahaan Yang Terdaftra dalam Indeks Syariah dan Indeks Konvensional Bursa Efek Indonesia. Proceeding Seminar Nasional dan Call for Papers Sancall. Surakarta.

Mashitoh, A. H. (2015). The Influence of Corporate Governance Implementation Toward bank Performance (Empirical Study on Banks Listed In Indonesia Stock Exchange). International Journal on Economics and Social Sciences Vol. 1 No. 1, 25-35.

Midiastuty, P. P. (2003). Analisis Hubungan Mekanisme Corporate Governance dan Indikasi Manajemen Laba. Simposium Nasional Akuntansi 6 Surabaya tanggal 16-17 Oktober . Surabaya: Simposium Nasional Akuntansi.

Nasution, M. d. (2007). Pengaruh Corporate Governance Terhadap Manajemen Laba di Industri Perbankan Indonesia. . Simposium Nasional Akuntansi X di Makassar, 26-28 Juli. 2007.

Peasnell, K. P. (2001). Board Monitoring and Earnings Management: Do Outside Directors Influence Abnormal Accruals. Accounting and Business Research, Vol. 30, Hal. 41-63.

Rahmawati, Y. S. (2006). Pengaruh Asimetri Informasi terhadap Praktik Manajemen Laba pada Perusahaan Perbankan Publik yang Terdaftar di Bursa Efek Jakarta. Symposium Nasional Akuntansi 9 tanggal 23-26 Agustus 2006. Padang.

Richardson, V. J. (1998). Information Asymetry an Earnings management:Some Evidence. Working paper.

Schipper, K. (1989). Comentary Katherine on Earnings Management. . Accounting Horizon.

Scott, W. (2003). Financial Accounting Theory, Third Edition, . Toronto: Prentice Hall, .

Tarigan, T. C. (2011). Pengaruh Asimetri Informasi, Corporate Governance dan Ukuran Perusahaan Terhadap Praktik Manajemen laba (Studi Pada Perusahaan Manufaktur Yang Terdaftar Di BEI). Yogyakarta: Fakultas Ekonomi Jurusan Akuntansi, Universitas Pembangunan Nasional Veteran Yogyakarta.

Ujiyantho, M. A. (2007). Mekanisme Corporate Governance, Manajemen Laba dan Kinerja Keuangan: Studi Pada Perusahaan Go Publik Sektor Manufaktur. Simposium Nasional Akuntansi (SNA) X,. 
Uwuigbe, U. P. (2014). The effects of corporate governance mechanisms on earnings management of listed firms in Nigeria". Accounting and Management Information Systems, Vol. 13 No. 1, pp. 159-174.

Veronica, S. d. (2004). Good Corporate Governance Information Asymetry and Earnings Management . Simposium Nasional Akuntansi 7 Denpasar Tanggal 2-3 Desember 2004. Denpasar.

Veronica, S. d. (2005). Pengaruh Struktur Kepemilikan, Ukuran Perusahaan, dan Praktik Corporate Governance Terhadap Pengelolaan Laba (Earnings Management). Simposium Nasional Akuntansi 8 Solo tanggal 15-16 September 2005. Solo.

Wedari, L. K. (2004). Analisis Pengaruh Dewan Komisaris dan Keberadaan Komite Audit Terhadap Aktivitas Manajemen Laba. Makalah Denpasar, 963-974.

Wilopo. (2004). The Analysis of Relationship of Independent Board of Directors, Audit Committee, Corporate Performance, and Discretionary Accruals. Ventura Volume 7 No. 1 April, 73-83.

Xie, B. (2001). Earnings Management and Corporate Governance The Roles of The Board and The Audit Comitte. Southhern Illinois University Carbonndale, July 5. 